\title{
What Is the Role of the Inflammation in the Pathogenesis of Heart Failure?
}

\author{
Elena C. Castillo ${ }^{1}$ (D) - Eduardo Vázquez-Garza ${ }^{1}$ (D) - David Yee-Trejo ${ }^{1}$ (D) $\cdot$ Gerardo García-Rivas ${ }^{1,2,3}$ (D) \\ Guillermo Torre-Amione ${ }^{1,2,4}$
}

Published online: 10 September 2020

(C) Springer Science+Business Media, LLC, part of Springer Nature 2020

\begin{abstract}
Purpose of Review In heart failure, whether it is associated with reduced or preserved ejection fraction, the immune system is activated and contributes to heart remodeling and impaired function.

Recent Findings Studies indicate that cells of the immune system not only play a role in the pathology but are also critical regulators of heart function. Knowledge about the role of the immune system driving heart failure will lead to the development of new targets to this system, particularly in those patients that, despite the apparent wellness, relapse and worsen.

Summary In this review, we will address the diverse mechanisms that trigger inflammation and their impact on heart failure progression.
\end{abstract}

Keywords Heart failure $\cdot$ Acute inflammation $\cdot$ Systemic inflammation $\cdot$ Inflammasome $\cdot$ Reduced ejection fraction and preserved ejection fraction

This article is part of the Topical Collection on Heart Failure

Gerardo García-Rivas

gdejesus@tec.mx

Elena C. Castillo

ecgonzalez@tec.mx

Eduardo Vázquez-Garza

eduardovzgz@tec.mx

David Yee-Trejo

a00815847@itesm.mx

Guillermo Torre-Amione

guillermo.torre@tec.mx

1 Tecnologico de Monterrey, Escuela de Medicina y Ciencias de la Salud, Ave. Morones Prieto 3000, 64710 Monterrey, NL, Mexico

2 Tecnologico de Monterrey, Centro de Investigación Biomédica, Hospital Zambrano Hellion, TecSalud, 66278 San Pedro Garza García, NL, Mexico

3 Tecnologico de Monterrey, Centro de Medicina Funcional, Hospital Zambrano Hellion, TecSalud, 66278 San Pedro Garzar García, NL, Mexico

4 De Bakey CRC, The Methodist Hospital, Cornell University, Houston, TX, USA

\section{Introduction}

Inflammation is a well-orchestrated process in which immune cells and tissues work together against pathogens and in the resolution of locally injured tissues to heal and restore homeostasis [1]. When acute local inflammation becomes chronic, it evolves systemic and becomes detrimental to our health [2]. Systemic chronic inflammation is a condition in which lifestyle plays an important role and can lead to non-communicable diseases such as cardiovascular disease (CVD) [3]. For instance, chronic stress and western diet are well-known factors that contribute to persistent sterile inflammation (induced by self-antigens) and the appearance of said diseases [3-5]. Inflammatory byproducts such as C-reactive protein (CRP), cytokines, and antibodies are associated with severity and with an increased risk of mortality [6-8]. Moreover, systemic inflammation predicts all-cause mortality $[9,10]$. Recently, Alpert, Shen-Orr, and colleagues generated an immunological age metric through cellular immune profiles and cytokine responses, which describe immune function better than their chronological age. In addition, it predicts all-cause mortality, including CVD [11]. In agreement, Furman, Faustin, and colleagues showed that elderly subjects with increased IL- $1 \beta$ and oxidative stress levels were associated with inflammasome genes that correlate with mortality and CVD risk [12]. 
Also, the neurohormonal pathways: renin-angiotensinaldosterone system (RAAS), sympathetic nervous system (SNS), and natriuretic peptides system, trigger immune pathway activation $[13,14]$. Thus, the fact that these mechanisms promote inflammation and that inflammation leads to HF indicates that the immune system plays a central role in HF progression. Moreover, recent studies indicate that cells of the immune system not only contribute to the pathology, but are also key regulators of heart function $[15,16]$, highlighting the role of immune system cells in heart homeostasis and the ability to respond and become activated.

Nowadays, despite the efforts, no pharmacological intervention introduced in the clinical guides to treat $\mathrm{HF}$ achieves direct modulation of the immune system with additional clinical benefits. Thus, unraveling the different immune pathways can help tackle a common player as a potential target. In this sense, inflammasome and B cell activation have demonstrated to play an important role in HF considering both inflammatory mechanisms activate during acute local inflammation [13, 17-20] and with associated risk factors, such as obesity and aging [21-23], which can contribute to low chronic systemic inflammation and declining heart function [24]. Some therapeutic strategies against both have already been tested in animal models and in a clinical context $[17,25,26]$. However, except for IL-1 $\beta$, a resultant product of inflammasome activation [27,28], none of them have been evaluated as possible targets in the different HF subclassifications. Here, we review the immunological pathways, both acute and chronic, that allow an inflammatory stimulus to persist and contribute to the development of HF, highlighting the common players in innate and adaptive immunity.

\section{Inflammation Pathways in HF}

HF can be sub-classified into three groups according to the ejection fraction (EF)s: $\geq 50 \%$ as $\mathrm{HF}$ with preserved ejection fraction (HFpEF), 40-49\% as HF with mid-range EF (HFmrEF), and < $40 \%$ as $\mathrm{HF}$ with reduced ejection fraction (HFrEF) [29]. HFmrEF is more frequently observed in patients with coronary artery disease and responds similarly to treatments for HFrEF with resembling features $[30,31]$. Thus, we are going to focus our attention on HFrEF and HFpEF. It has been suggested that HFpEF and HFrEF have distinct inflammatory features. Biomarkers measured in patients with ischemic and nonischemic HF found that HFpEF was more associated with inflammatory markers, as opposed to HFrEF, which was more related to biomechanical cardiac stress markers such as BNP $[32,33]$. In this regard, it has been postulated that HFpEF results from a chronic pro-inflammatory state induced by comorbid conditions such as obesity, hypertension, and diabetes, which triggers microvascular endothelial cell inflammation and stress oxidation, whereas HFrEF is mainly promoted by a direct cardiac insult as occurs in myocarditis or ischemia [34]. However, as a result of cardiac insults, molecular patterns associated to damage or pathogens (DAMPs and PAMPs, respectively) are generated and presented leading to inflammatory features that have been widely studied in patients with HFrEF, such as inflammatory innate/adaptive cells activation, cytokines, and autoantibodies against cardiac antigens; all of them associated with severity, poor prognosis, and rehospitalization $[6,7,35,36]$. These studies have allowed the development of new therapeutic approaches by recognizing the role of immune cells, particularly adaptive immunity, as a key player in sustained inflammation and disease progression [19, 25]. Despite both types of HF having different triggers and cellular interplay, end-stage HF derived from either type share many etiology independent features. However, since the primary inflammatory mechanisms described are from studies on HFrEF, in both human and animal models, the role of inflammation in HFpEF remains to be clarified [35-37]. It is worth noting that many of the currently available therapies have shown improvements in the clinical outcomes of patients with HFrEF but not with HFpEF [30], an etiology with a rising prevalence [38]. A different pattern of circulating inflammatory cytokines was reported in rats with HFrEF (ligation of the left coronary artery) showing higher TNF- $\alpha$ plasma levels as opposed to HFpEF (high-salt diet) which demonstrated higher IL-1 $\beta$ and IL12 levels [39]. Therefore, understanding the inflammatory process in both types of HF could allow us not only to unravel the differences, but also to suggest specific therapies for HFpEF instead of transposing them from HFrEF or even find a common player as a therapeutic target.

\section{Cardiac Injury Activates Inflammatory Pathways}

Cardiac acute local inflammation is a process with a vast array of causes; these vary from infectious, toxins [40], or myocardial infarction. Infectious inflammatory myocarditis may be associated with viruses, bacteria, fungal entities, or parasites. From these, viral myocarditis is of particular interest due to its progression to dilated cardiomyopathy (DCM) and HF [41]. From an inflammatory standpoint, most viral infections can be cleared without sequelae. However, some infections are associated with cardiomyocyte lysis after entering these cells and releasing self-antigens. Cardiomyocytes have a higher rate of being infected than fibroblasts, although the latter have higher replication rates [42]. After infection, the host mounts an inflammatory response through the production of several pro-inflammatory cytokines, such as IL- $1 \alpha$, IL-6, TNF- $\alpha$, IFN- $\gamma$, and the activation of monocytes and NK cells, which induce apoptosis in infected cells [43]. As mentioned previously, viral myocarditis is linked to DCM, and although not well understood, in any cardiac inflammatory setting, there is a risk to develop chronicity, as has been recently shown by Groot and Hilde, from non-obstructive cardiovascular disease to ischemic HF [44]. The interplay of increased cytokines also skews T cells between Th1/Th2 and Th17/Treg responses $[45,46]$, each with specific inflammatory functions, yet all associated with chronic inflammation when skewed. 
During an ischemic event, the neutrophils are the first cells to arrive and infiltrate the tissue, and it has been demonstrated that the basal levels can predict the progression to ischemic HF [44]. Once in the myocardium, influenced by the release of inflammatory cytokines, neutrophils activate and release a series of inflammatory mediators such as high levels of reactive oxygen species (ROS), IL-1 $\beta$, myeloperoxidase, and proteases, which increase local tissue injury [47]. Of note, the increase in neutrophil counts and/or its ratios, such as neutrophil: lymphocytes and neutrophil: platelet ratio $[48,49]$, have demonstrated to have clinical relevance in stratifying a patient's severity. This cytokine-mediated inflammation contributes to inflammatory loops and induces sub-acute and chronic inflammation [50]. Persistence of this inflammatory response causes additional secondary damage to the nearby tissue. There is also enough evidence of the effect of inflammation influencing the dysfunctional contractile state in HF, for example, by TNF- $\alpha$ [51]. Finally, some specific neutrophils can induce polarization of monocytes to a reparative phenotype, inducing a pathologic production of fibrosis [52].

The inflammatory response to the pathogens, infected cells, and damaged cells/tissues, which release DNA and ROS [20, 50], elicits the activation of pattern recognition receptors (PRR), such as toll-like receptors (TLRs) and nucleotidebinding and oligomerization domain- (NOD-) like receptors (NLRs) as NLRP3 (NOD-, LRR-) associated with the inflammasome. NLRP3 inflammasome activation results in IL-1 $\beta$ and IL-18 cytokine production, both related to cardiac dysfunction, reduced left ventricular contractility, worsening, and increased mortality $[53,54]$. On the one hand, IL- $1 \beta$ promotes contractile dysfunction and secondary cytokineinduced damage $[50,54,55]$. In the cardiomyocytes, IL- $1 \beta$ promotes systolic dysfunction by altering mitochondrial function [56] and decreasing $\beta$-adrenergic responsiveness of Ltype calcium channels and connexin $43[57,58]$. On the other hand, IL-18 induces neutrophil accumulation and activation [59]. Recent evidence shows that after an inotropic stimulus, IL-18 is produced as early as $1 \mathrm{~h}$ and remains at $72 \mathrm{~h}$, whereas IL- $1 \beta$ and TNF- $\alpha$ become expressed until $72 \mathrm{~h}$ of the stimulus [13]. Furthermore, $\beta$-adrenergic receptor $(\beta-\mathrm{AR})$ activation seems to specifically induce IL-18 maturation in the heart but not in the spleen, lung, liver, or kidneys. These elevated levels of IL-18 were primarily detected in cardiomyocytes within the first hour and then in macrophages after $24 \mathrm{~h}$ [13], indicating that the inflammasome pathway is primarily driven by cardiomyocytes in response to neurohormonal activation. In turn, IL-18 induces $\beta$-adrenergic responsiveness that associates with LV dysfunction [60] and promotes BNP synthesis [61]. Therefore, targeting the inflammasome pathway has been suggested as an important therapeutic step as caspase- 1 inhibition has demonstrated to have a protective effect on ischemia-induced human myocardial dysfunction through inhibition of the IL-18 and IL- $1 \beta$ processing [26,
$60,62]$. An example of this is 16673-34-0 (5-chloro-2methoxy-N-[2-(4-sulfamoylphenyl) ethyl]benzamide), an intermediate substrate free of the glyburide synthesis, which has shown benefits in ischemia-reperfusion animal models by reducing the infarct area without affecting glucose consumption and metabolism [63, 64]. The activation of the inflammasome pathways through IL-18 contributes with adaptive immunity regulation and thus with long-term responses by $\mathrm{B}$ and $\mathrm{T}$ cells, specifically favoring Th1/Th2 imbalance by the activation of Th1 cells and by modulating Th2 and Th17 responses [60]. The IL-18/IL-12 axis is considered the master controller of the Th1 response, giving a rise in the high level of production of IFN- $\gamma$, which also enhances B cell response $[65,66]$, including maturation and isotype switching [67, 68]. Hence, inflammasome activation seems to play an important role as a bridging pathway between innate and adaptive responses that contribute to HF development.

The risk of chronic inflammation to become systemic is also closely related to the induction of an autoimmune scenario, where the initial damage of the tissue is associated with the presentation of an antigen or a similar self-antigen, thereby initiating the damage modulated by CD4 cells and promoted by $\mathrm{CD} 8$ cytotoxic cells by its perforin, granzyme, and FASmediated apoptosis induction mechanism. Alongside the effects of T cells, B cells have an active and critical role in the development of HF remodeling and dysfunction [7, 17-19], either by modulating inflammatory cell recruitment $[16,18]$ or by increasing the inflammatory response through the production of autoantibodies [7] and fibrosis [19]. Moreover, interfering $\mathrm{T}$ cell co-stimulation by antigen presenting cell (dendritic cell, macrophages, and B cells) attenuates heart dysfunction mediated by IL-10-producing B cells [69].

An overview of the general immune players in the development of HFrEF is shown in Fig. 1.

\section{The Heart as a Target of Systemic Inflammation}

Chronic systemic inflammation induced by conditions such as obesity, hypertension, autoimmunity, and aging increases the risk to develop CVD and progress to HF [10, 70, 71]. Despite, the current understanding about the progression to HF, gleaned by the knowledge of the inflammatory pathways that are induced in these conditions, a recent mouse model, consisting of a combination of a high-fat diet (HFD) plus LNAME has demonstrated a resemblance with human HFpEF pathophysiology since 5 weeks of treatment that remained until a year of follow-up [72••]. This model elicited a systemic proinflammatory state and, therefore, may provide a useful tool in understanding the inflammatory process that leads to $\mathrm{HF}$ and, in turn, to determine the immune features that play a critical role in HF development and to propose or test new therapeutic strategies for patients with HFpEF. Although previous animal models of HFpEF were established with rats [73, 


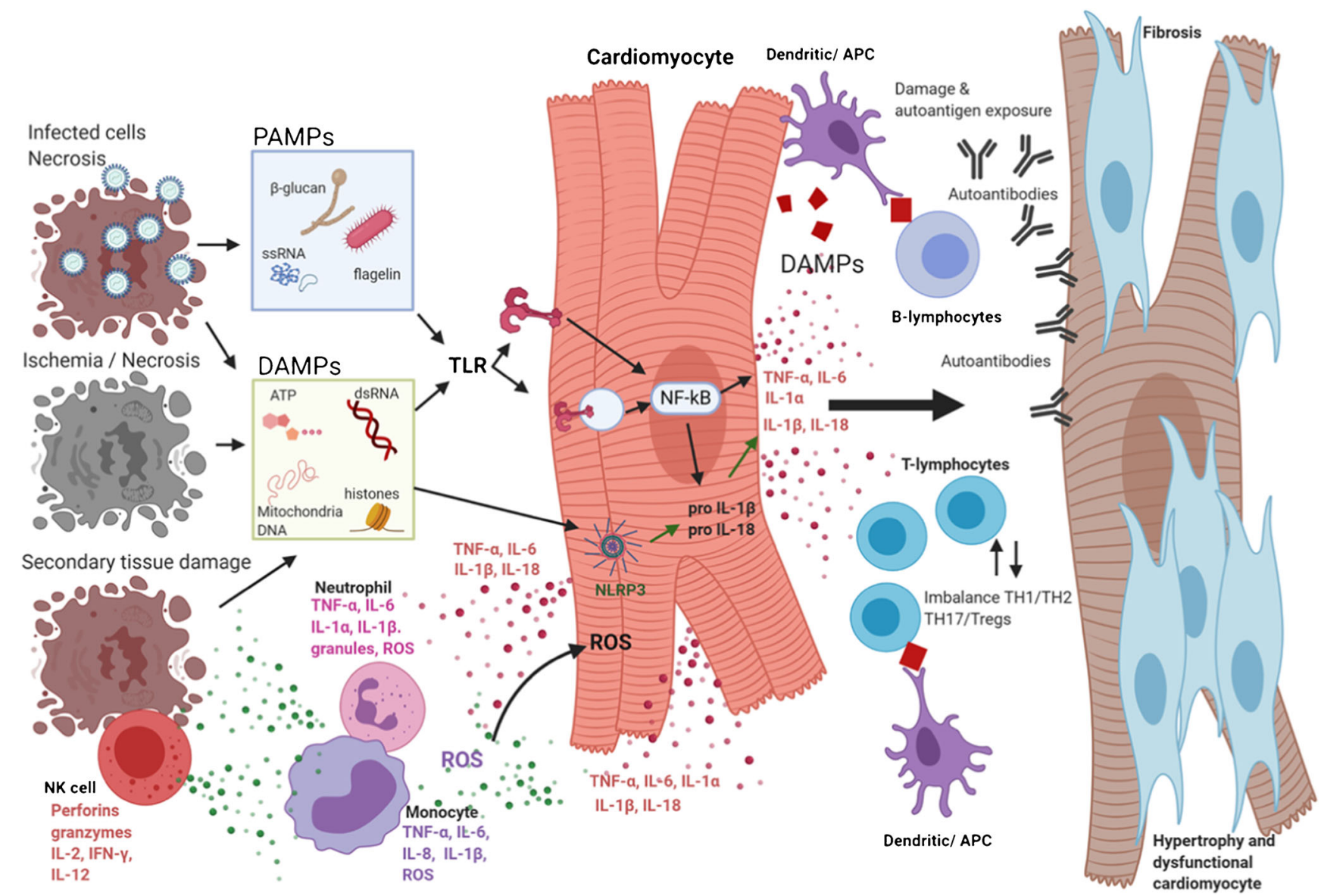

Fig. 1 Role of acute local inflammation in HF. From acute to chronic inflammation. There is an interplay of both the innate and adaptive immune system in the development of inflammatory cardiovascular disease and its contribution to HF. The initial effect of PAMPs and DAMPs to TLRs pathways promotes the synthesis of inflammatory cytokines through $\mathrm{NF} K \mathrm{~B}$. In a 2 nd phase, NLRP3 activation promotes the maturation and secretion of IL-1 $\beta$ and IL-18. TLR and NLRP3 activation on cardiomyocytes contributes to pro-inflammatory cytokine production that is enhanced by APCs, such as DCs, macrophages, and B cells. This mechanism, if unchecked, can contribute to secondary tissue

74] or swine [75], mouse models are more suitable for the immunological study approach with broader technical availability resources [76].

Despite the aforementioned, it is well recognized that chronic systemic inflammation is the keystone player in HFpEF by promoting coronary microvascular endothelial inflammation, oxidative stress, lowering nitric oxide, and cardiomyocytes loss [77]. Furthermore, inflammatory mediators can induce direct activation in cardiac resident immune cells, such as macrophages and B cells, which also contribute to normal cardiac function $[15,16]$ and regulate the traffic of immune cells [16••]. Therefore, B cells may be responsible for monocyte infiltration, as observed in a myocardial infarction model [18], and also contribute to cardiac dysfunction in a non-classical way. damage by humoral and cellular mechanisms by $\mathrm{B}$ and $\mathrm{T}$ cell driving mechanisms of chronic inflammation, leading to pervasive cell phenotype skewing, antibody production, and eventual fibrosis and cell contractile dysfunction. APC, antigen presenting cell. DAMPS, damageassociated molecular patterns. IL, interleukin. IFN, interferon, PAMPs pathogen-associated molecular patterns. TLR, toll-like receptors. TH, Thelper cell. Tregs, regulatory T cell. TNF, tumor necrosis factor. ROS, reactive oxygen species. ATP, adenosine triphosphate. DSRNA, doublestranded RNA. SSRNA, single-strand RNA, $\mathrm{T}_{\mathrm{H}}$, T-helper cell

In obesity, local inflammation in adipose tissue induces innate and adaptive cell infiltration promoting a low-grade chronic systemic inflammatory state that involves the secretion of proinflammatory cytokines, adipokines, and IgG immunoglobulins $[78,79]$. We recently demonstrated that significant weight loss after bariatric surgery results in systemic inflammation markers such as normalization of CRP levels, decreases in the B cell activation factors, and inflammasome activation byproducts (unpublished data). The decreased inflammation by bariatric surgery-induced weight loss reduces CVD risk [80].

Animal models with obesity display mitochondrial hyperacetylation, fragmentation, ROS production, and mitochondrial permeability transition pore openings with diastolic dysfunction [81-83]. All these changes contribute to 
mitochondrial DNA (mtDNA) release and systemic inflammation [84] that, in conjunction with ROS, are inflammasome activators involved in heart inflammation [85]. As a result, IL18 secretion may induce fibrosis and cardiac hypertrophy resulting in diastolic stiffness [86] and concentric remodeling [87], whereas IL-1- $\beta$ can induce diastolic dysfunction by altering calcium handling, decreasing the expression of SERCA (sarcoplasmic reticulum calcium ATPase), and phospholamban (PLB) and, therefore, calcium recaptured [56].

As well as in obesity, hypertension, and aging also contribute to HF that involves systemic oxidative stress and inflammation [88-90], which leads to a coronary microvascular endothelial dysfunction [91] with fibroblast proliferation associated with the decrease in NO [92] and diastolic dysfunction [75]. Furthermore, inflammasome-genesexpression associated with chronic inflammation and mortality was linked with IL- $1 \beta$, oxidative stress, and nucleotide metabolism dysfunction [12]. With this, NLRP3 inflammasome may be considered as a clinical target in HFpEF (Fig. 2).

Autoimmunity is widely recognized as a $\mathrm{CV}$ risk factor that correlates with the duration of the disease and mortality risk as a result of chronic systemic inflammation [70, 93-95]. Other supporting data that indicates that systemic inflammation is an important associated mechanism is that the acute systemic inflammation occurring after infections, as is the case of SARS-CoV virus, increases the risk of CVD and more associated event years after the disease resolution [96]. This suggests that acute systemic inflammation can "prime" cells of the immune system in the heart and make them more prompt to become activated and develop HF. Therefore, patients that currently course with a SARS-CoV-2 infection, associated with a cytokine storm [97], might have acquired an additional risk factor to developed CVD and HF.

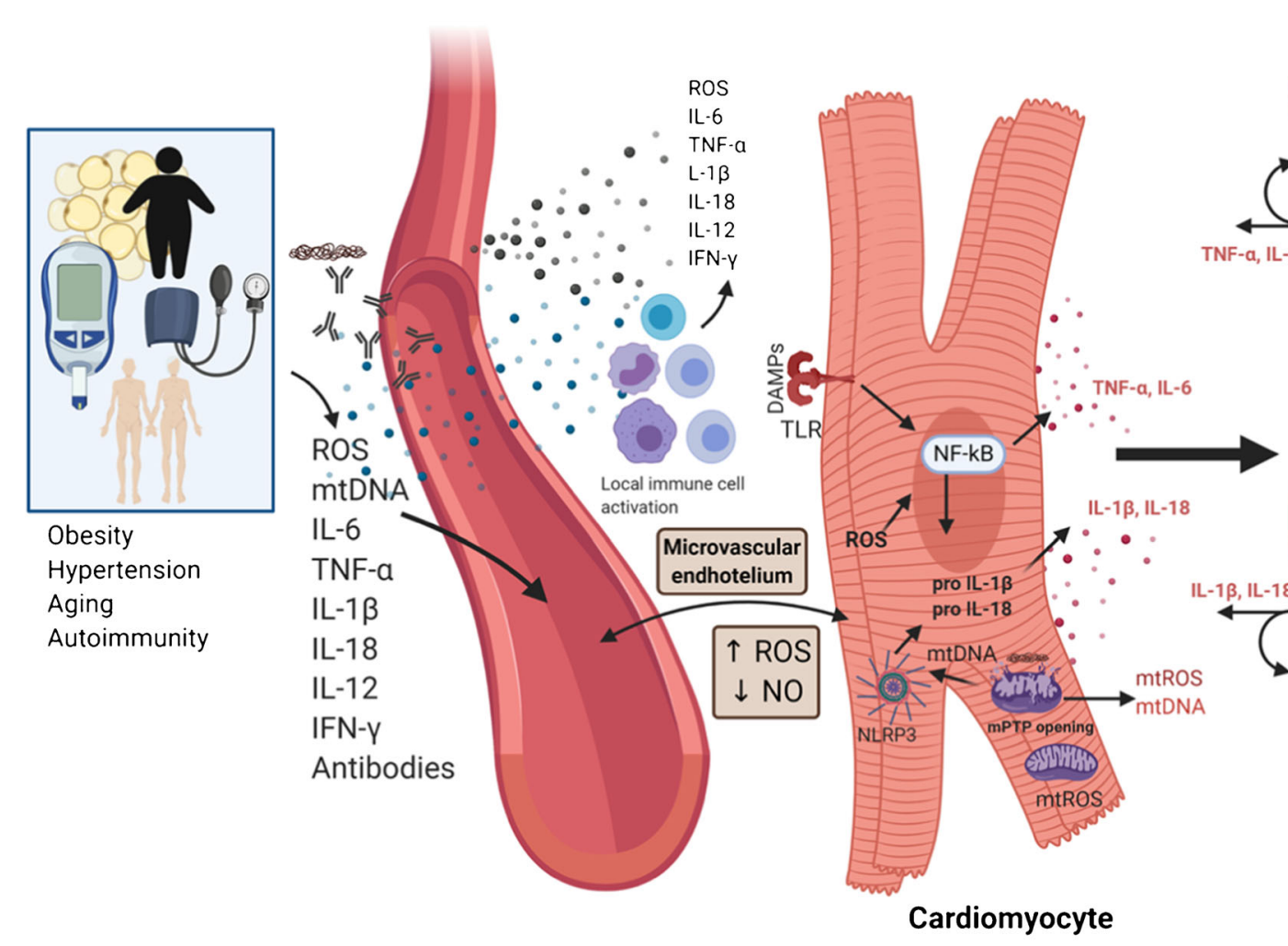
Hypertrophy and
dyastolic dysfunction

Obesity

Hypertension

Aging

IL-18

$L-12$

$\mathrm{FN}-\mathrm{Y}$ Antibodies
Cardiomyocyte

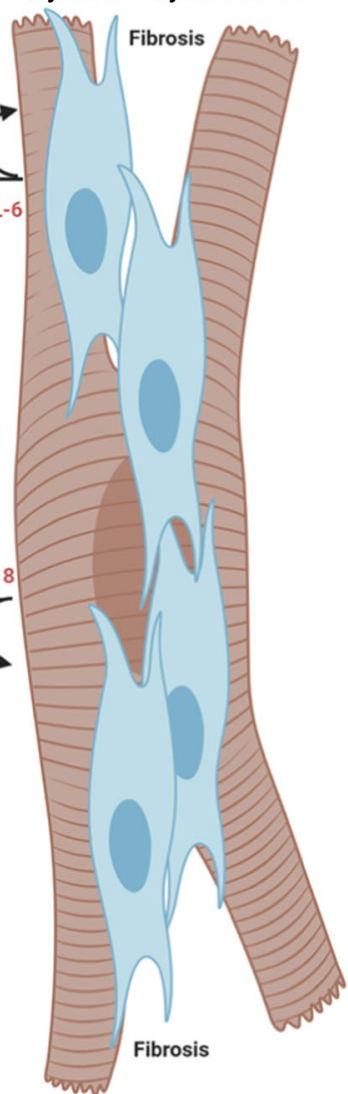

production of more inflammatory cytokines and DAMP mediators such as ROS. These events lead to immune cell shifts, pathologic tissue remodeling, hypertrophy, dysfunction, and continuous inflammatory cell signaling. IL, interleukin; IFN, interferon; NO, nitric oxide; TLR, toll-like receptors; TNF, tumor necrosis factor; ROS, reactive oxygen species; mt-DNA, mitochondrial DNA; mt-ROS, mitochondrial reactive oxygen species
Fig. 2 Role of systemic chronic inflammation in the development of HF: from systemic to heart inflammation. There is direct modulation of inflammatory diseases and cellular events like obesity in TLR and NLRP3 inflammasome activation. The inflammatory cytokines alongside DAMPs, and the combination of both the innate and adaptive immune system activation affect the vascular endothelium cells. Therefore, this has an impact in the cardiomyocyte. This continuous inflammatory loop allows for pathologic damage, increasing the 


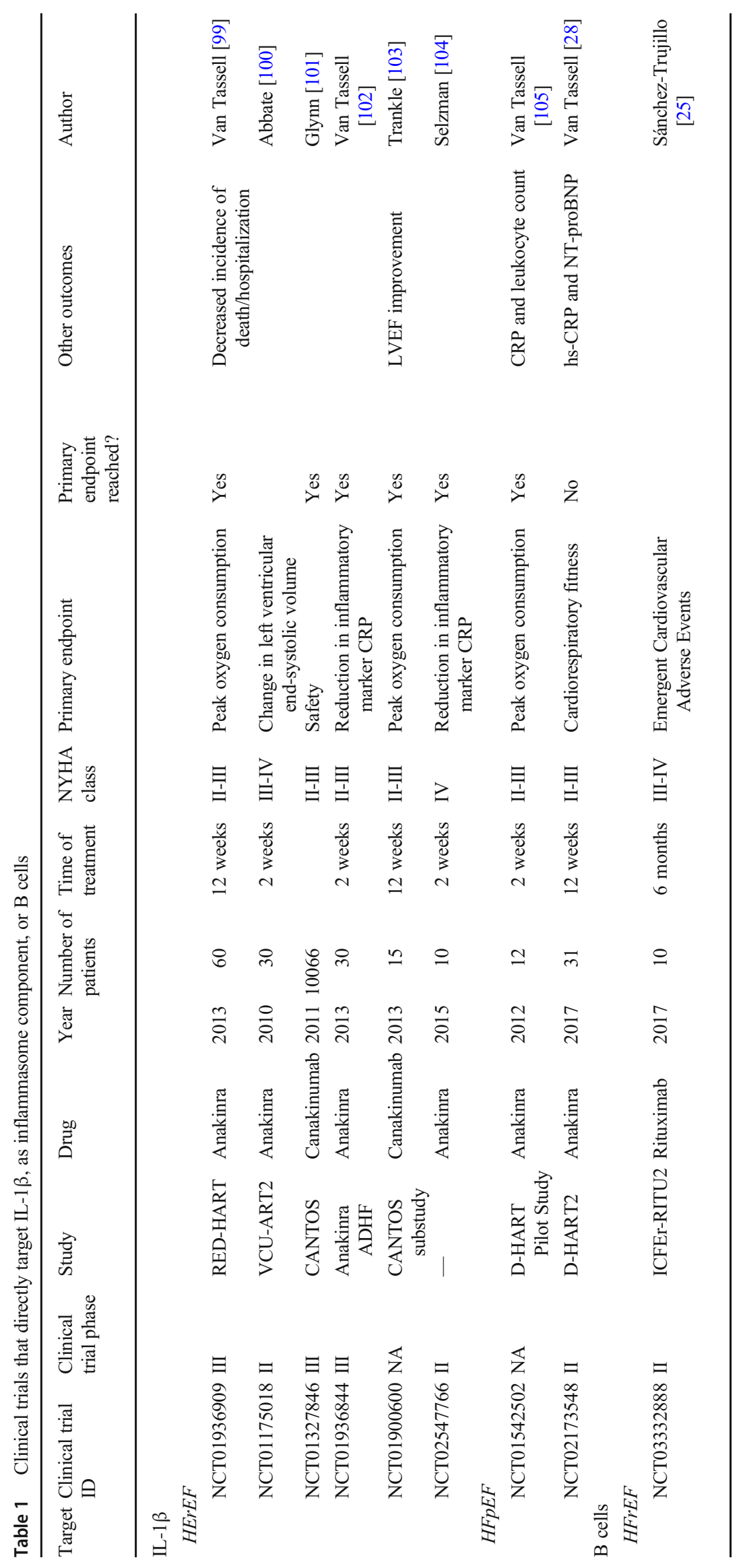




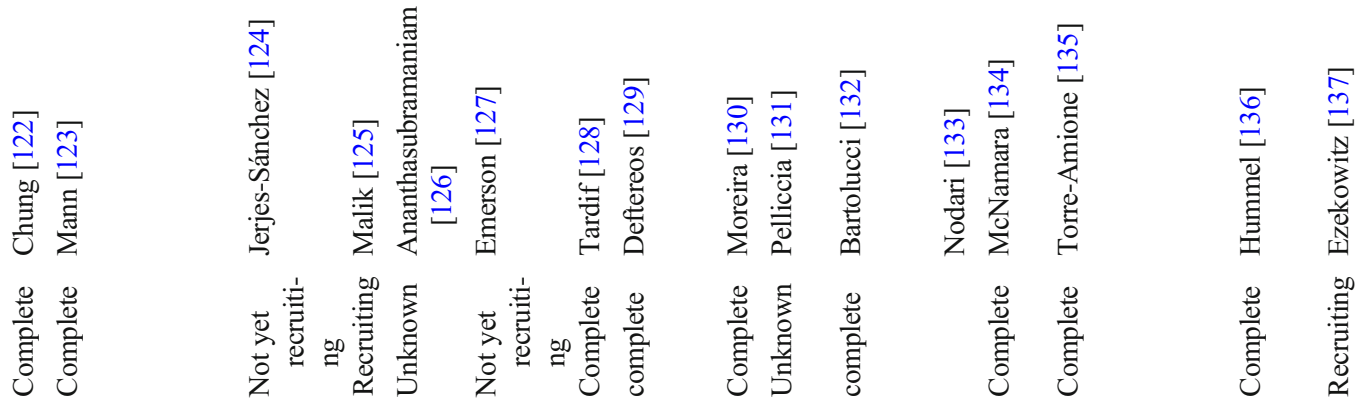

z̊ z

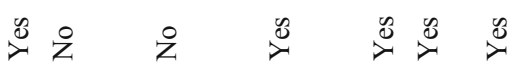

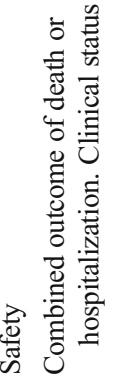
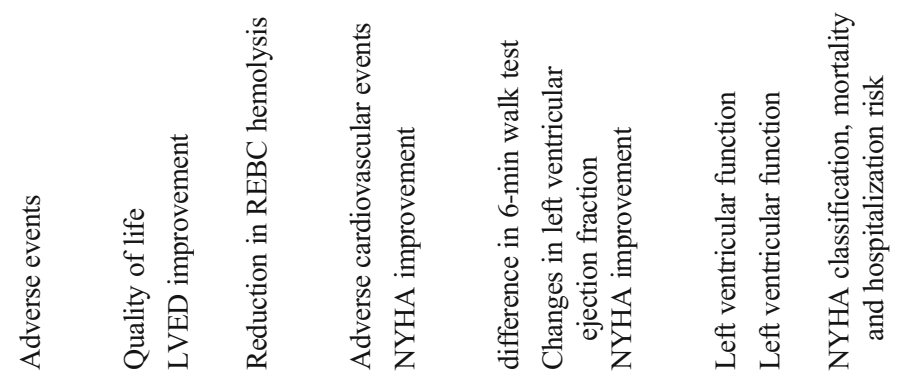

$\frac{3}{\frac{z}{c}}$

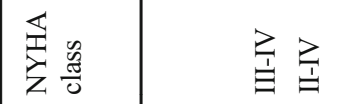

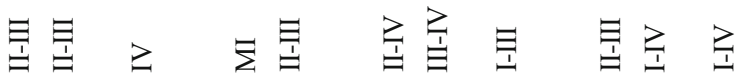

䍐

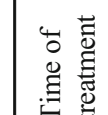

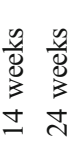

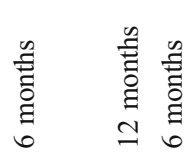

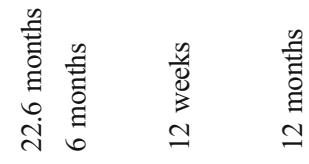

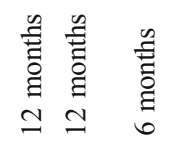

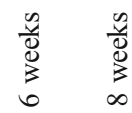

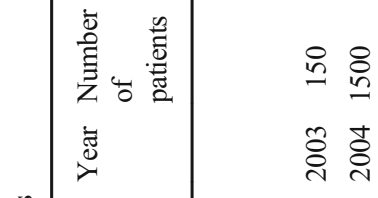

ำ

in $\frac{1}{4}$

in\&

$\stackrel{m}{2} \mathfrak{c}$

$\because$ q

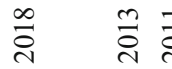

을

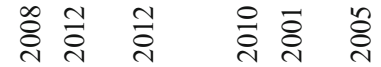

융

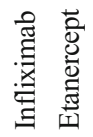

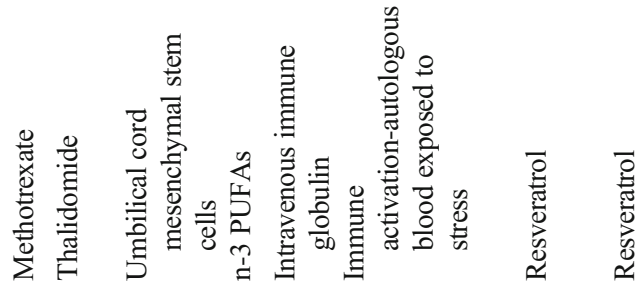

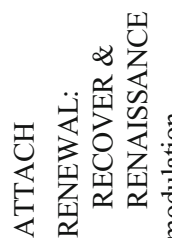

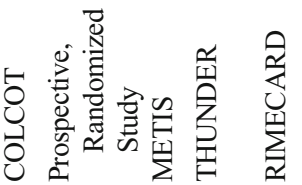

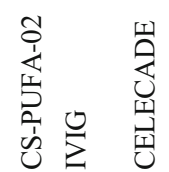

空

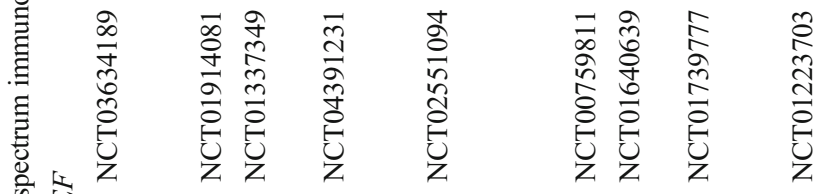

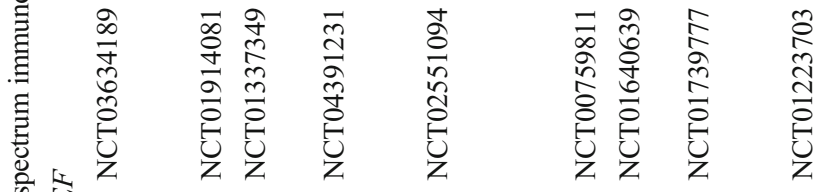

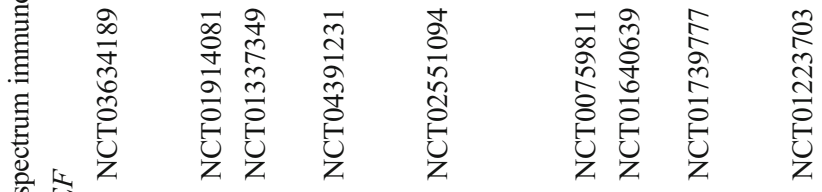

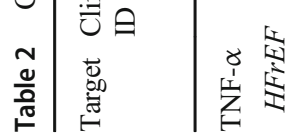


Targets for Therapeutic Intervention

Inflammasome Activation (Innate Immunity)

Therapies associated with blocking the NLRP3 inflammasome have yielded promising results. An example of this, as previously mentioned, is the glyburide analog, 16673-34-0, that has shown benefits in ischemia-reperfusion animal models $[63,64,98]$. Although no clinical trials are being conducted to target NLRP3 directly, IL-1 $\beta$, a byproduct resulting from NLRP3 activation, has revealed beneficial outcomes associated to inflammation resolution in both HFrEF and HFpEF. Several clinical trials (Table 1) [27, 28, 99, 106] have shown a risk reduction in nonfatal stroke or cardiovascular death alongside hospitalization of unstable angina after myocardial infarction [27.•] as well as in patients with endstage acute decompensated heart failure [102] with early positive results regarding aerobic capacity and ventilatory efficiency [99]. In infectious and septic myocarditis, they have shown positive effects of improvement and recovery [107, 108]. Moreover, patients with rheumatoid arthritis receiving this therapy reveal improvement in LVEF and LVESVi [109, 110]. Regarding HFpEF, a reduction of ongoing inflammation and cardiac stress biomarkers (high-sensitivity-CRP and NTpro-BNP, respectively) was observed but with opposing results regarding aerobic capacity that was the primary goal of the study [28] and was previously observed in a pilot study [105]. As investigators point out, this discrepancy might be associated with the greater grade of obesity in the second study which alters the aerobic capacity by its own condition (median body mass index $=42$ ) [28]. Additionally, IL-18 secretion is not altered by IL-1 $\beta$ inhibition [111] and as we mentioned before, IL-18 is primary secreted by the cardiomyocytes [13] and is also important during chronic inflammation as occurred in obesity [112]. Thus, clinical trials targeting inflammasome might be promising.

\section{B Cells (Adaptive Immunity)}

B cell activation plays a central role leading to chronic and systemic inflammation as observed by the increase presence of serum/plasma immunoglobulins, either intact or as a free light chains in patients with HF $[113,114]$ and associated comorbidities [79, 115]. Moreover, the presence of anticardiac antibodies in failing heart biopsies demonstrates their relevance in cardiac dysfunction $[7,113]$. In this context, therapeutic plasma exchange performed in patients with HFrEF with NYHA functional class II-IV not only improved cardiac function but also showed less $\operatorname{IgG}$ cardiac deposition after 6 months of treatment [116]. Notably, recent data in a murine model demonstrates that B cell subpopulations $\left(\mathrm{CD} 19^{+} \mathrm{CD}_{\left.11 \mathrm{~b}^{+/}\right)}\right)$have a specific patrolling role in the heart with functional relevance, by regulating other immune cell 
Fig. 3 Common inflammation pathways that have shown an impact in detrimental cardiac function and heart failure. $\mathrm{IgG}$, immunoglobulin G; IL-, interleukin; ROS, reactive oxygen species; mt-DNA, mitochondrial DNA; mt-ROS, mitochondrial; NLRP3, NOD-, LRR-, and pyrin domain-containing protein 3 ; NF$\mathrm{kB}$, nuclear factor $\mathrm{kB}$

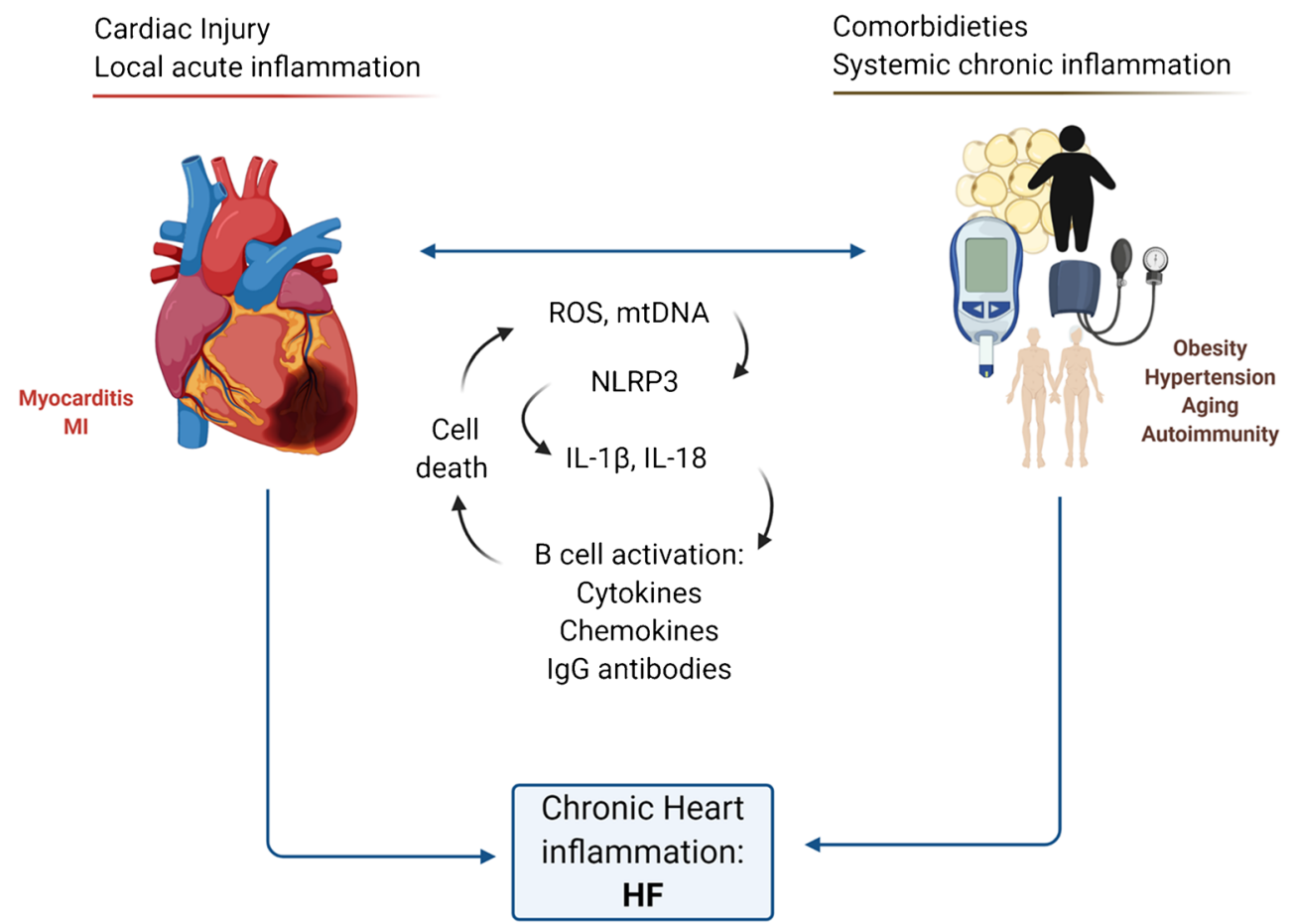

trafficking and heart function [16••]. In fact, $\mathrm{CD} 19^{+} \mathrm{CD} 11 \mathrm{~b}^{-} \mathrm{B}$ cells are associated with cardiac fibrosis [19], which is in line with data for depleting B cells that indicates that B cells are involved in fibrosis, heart dysfunction, and hypertension [17, $18,117]$.

Although these findings are difficult to study on heart biopsies under physiological conditions, B cells were observed in close contact with the cardiac endothelium and, to a lesser extent, in the myocardium in failing heart biopsies [16••]. Indeed, in patients, the uses of rituximab-a selective CD20-B cells depleting antibody - showed clinical improvement [118]. Ongoing phase I/II clinical trials in patients with HFrEF and an acute ST segment elevation myocardial infarction were recently submitted (Table 1) $[36,119]$ but none of them involved patients with HFpEF. Detailed information regarding $\mathrm{B}$ cell mechanism involved in HF and targeting approaches has been recently reviewed [120].

\section{Other Strategies Targeting Immune System}

After the TNF- $\alpha$ clinical trials (previously reviewed) [121-123], multiple therapies have been postulated using mostly broad spectrum immunomodulators. However, most have been tested mainly on patients with HFrEF (Table 2). Recently, molecules with anti-inflammatory and antioxidative properties have gained some attention such as resveratrol and cannabidiol (CBD) with recent ongoing clinical trials [124]. The potential of these molecules to be effective at targeting both, HFrEF and HFpEF, relies on the fact that in both conditions, mitochondrial dysfunction and ROS production are associated with cardiomyocytes cell death, DAMPs released (inflammation), and ultimately HF (Fig. 3) [81, 82, 138]. For instance, CBD directly reduces mitochondrial oxidative stress and cardiomyocyte hypertrophy (in vitro) and impairs cardiac remodeling and systemic inflammation in a model of HF with systolic dysfunction [139].

Other molecules that have shown immunomodulation properties with ongoing clinical trials are pentoxifylline, colchicine, statins, methotrexate, thalidomide, and allopurinol, among others. Pentoxifylline is a methylxanthine derivative that has demonstrated the capacity to interfere with TLR and inflammasome signaling pathways, as well as with the expression of CD80 costimulation molecule [140]. Sequentially, the impaired danger signals recognition and APC-T cell costimulation results in clinical improvement in patients with HFrEF and could potentially be beneficial for HFpEF due to the involved mechanisms [141, 142]. In this context, colchicine, which inhibits microtubule polymerization, interferes with NLRP3 activation and thus IL-1 $\beta$ and IL-18 secretion. However, this effect only showed decreased inflammatory biomarkers without changes in the clinical outcomes in patients with HFrEF treated for 6 months [129]. Nonetheless, a larger clinical trial with a follow-up of more than 20 months found that colchicine treatment lowered the risk of ischemic cardiovascular events [128]. On the contrary, statins, which seem to modulate the inflammatory response by restoring NO and endothelial function [143] which is the primary inflammatory pathway described in HFpEF patients, did not demonstrate any effect in chronic HF, independent of NYHA 
functional class, and left ventricular ejection fraction [144]. This suggests that once chronic inflammation is established, alleviating endothelial dysfunction is not enough to rectify the inflammatory loop. Studies with methotrexate, thalidomide, and allopurinol showed neutral results, in small sized clinical trials (Table 2).

\section{Conclusions}

It has already been proposed that the cross-talk between heart and peripheral tissues may be importantly mediated by NLRP3 inflammasome [145]. NLRP3 activation is strongly associated with the oxidative stress that occurs in both kinds of damage in cardiomyocytes, acute local $[138,146]$, and chronic systemic inflammation $[81,82]$. This could explain why blocking IL-1 $\beta$ has shown promising results in both HFrEF and HFpEF [27, 28]. Given that IL-18 seems to play an essential role in both etiologies, targeting inflammasome may provide further beneficial outcomes. Furthermore, recent findings have shown that IL-1 $\beta / N L R P 3$ pathway associates with age-related hematopoietic stem cells clonal expansion that associates with increased CVD risk and all-cause mortality [147]. On the other hand, adaptive immunity is fundamental to sustain and establish a higher affinity and quicker response to the original stimuli by generating memory. In this context, $\mathrm{B}$ cells stand out because they can directly recognize the antigen, modulate other immune cells ( $\mathrm{T}$ cells, monocytes), and release cytokines and antibodies that modulate the inflammatory response. This approach has already been testing in HFrEF $[25,118]$ but not in HFpEF. Given that the cellular immune system can help predict CVD mortality [11], knowing precise subpopulations may provide the opportunity to establish the right anti-inflammatory strategy depending on the ongoing inflammatory response. Lessons learned from current clinical trials, not only for HF but also in other pathologies that target common immune characteristics present in heart failure or that have demonstrated positive effects on heart function as occurs in patients with autoimmune diseases, could help to translate these findings into therapeutic strategies for patients with HF. For example, protocols with rituximab have demonstrated that patients with elevated pre-switch memory B cells $(\mathrm{CD} 19+\mathrm{IgD}+\mathrm{CD} 27+\mathrm{CD} 95-)$ associate with adverse outcomes [148]. Therefore, immunotyping B cells in heart failure patients could avoid these effects.

Funding This work was partially supported by the GIEE Medicina Cardiovascular y Metabolomica (Tecnologico de Monterrey, 0020209M01) as well as the CONACYT Grants 151136, 133591, 269399, Fronteras de la Ciencia Grant (0682).

Data Availability The datasets generated during and/or analyzed during the current study are available from the corresponding author on reasonable request.

\section{Compliance with Ethical Standards}

Conflicts of Interest Gerardo García-Rivas and Guillermo TorreAmione are co-founders of Nano4Heart, a start-up company focused on developing immunotherapies for the treatment of heart failure. The other authors declare no competing interests.

Human and Animal Rights and Informed Consent This article does not contain any studies with human or animal subjects performed by any of the authors.

\section{References}

Papers of particular interest, published recently, have been highlighted as:

- Of importance

•- Of major importance

1. Newton K, Dixit VM. Signaling in Innate Immunity and Inflammation. Cold Spring Harb Perspect Biol [Internet]. 2012 [cited 2020 May 21];4. Available from: https://www.ncbi.nlm. nih.gov/pmc/articles/PMC3282411/

2. Ajaikumar B. Kunnumakkara, Bethsebie L. Sailo, Kishore Banik, Choudhary Harsha, Sahdeo Prasad, Subash Chandra Gupta, Alok Chandra Bharti and Bharat B. Aggarwal, et al. Chronic diseases, inflammation, and spices: how are they linked? [Internet]. Journal of translational medicine. J Transl Med; 2018 [cited 2020 May 21]. Available from: https://pubmed.ncbi.nlm.nih.gov/ $29370858 /$ ?from term $=$ ACUTE+AND+CHRONIC+ INFLAMMATION\&from_pos $=4$

3. Furman D, Campisi J, Verdin E, Carrera-Bastos P, Targ S, Franceschi C, et al. Chronic inflammation in the etiology of disease across the life span. Nat Med. 2019;25:1822-32.

4. Liu Y-Z, Wang Y-X, Jiang C-L. Inflammation: the common pathway of stress-related diseases. Front Hum Neurosci [Internet]. 2017 [cited 2020 May 21];11. Available from: https:/www.ncbi. nlm.nih.gov/pmc/articles/PMC5476783/

5. Christ A, Günther P, Lauterbach MAR, Duewell P, Biswas D, Pelka K, et al. Western diet triggers NLRP3-dependent innate immune reprogramming. Cell. 2018;172:162-75 e14.

6. Torre-Amione G, Kapadia S, Benedict C, Oral H, Young JB, Mann DL. Proinflammatory cytokine levels in patients with depressed left ventricular ejection fraction: a report from the studies of left ventricular dysfunction (SOLVD). J Am Coll Cardiol. 1996;27:1201-6.

7. Youker KA, Assad-Kottner C, Cordero-Reyes AM, Trevino AR, Flores-Arredondo JH, Barrios R, et al. High proportion of patients with end-stage heart failure regardless of aetiology demonstrates anti-cardiac antibody deposition in failing myocardium: humoral activation, a potential contributor of disease progression. Eur Heart J. 2014;35:1061-8.

8. Mallat Z, Heymes C, Corbaz A, Logeart D, Alouani S, CohenSolal A, et al. Evidence for altered interleukin (IL)-18 pathway in human heart failure. FASEB J. 2004;18:1752-4.

9. Proctor MJ, McMillan DC, Horgan PG, Fletcher CD, Talwar D, Morrison DS. Systemic inflammation predicts all-cause mortality: a Glasgow inflammation outcome study. PLoS One. 2015;10: e0116206.

10. Roth GA, Abate D, Abate KH, Abay SM, Abbafati C, Abbasi N, et al. Global, regional, and national age-sex-specific mortality for 282 causes of death in 195 countries and territories, 1980-2017: a 
systematic analysis for the Global Burden of Disease Study 2017. The Lancet Elsevier. 2018;392:1736-88.

11. Alpert A, Pickman Y, Leipold M, Rosenberg-Hasson Y, Ji X, Gaujoux R, et al. A clinically meaningful metric of immune age derived from high-dimensional longitudinal monitoring. Nat Med. 2019;25:487-95.

12. Furman D, Chang J, Lartigue L, Bolen CR, Haddad F, Gaudilliere $\mathrm{B}$, et al. Expression of specific inflammasome gene modules stratifies older individuals into two extreme clinical and immunological states. Nat Med. 2017;23:174-84.

13. Xiao H, Li H, Wang J-J, Zhang J-S, Shen J, An X-B, et al. IL-18 cleavage triggers cardiac inflammation and fibrosis upon $\beta$ adrenergic insult. Eur Heart J. 2018;39:60-9.

14. Sekiguchi K, Li X, Coker M, Flesch M, Barger PM, Sivasubramanian N, et al. Cross-regulation between the reninangiotensin system and inflammatory mediators in cardiac hypertrophy and failure. Cardiovasc Res Oxford Acad. 2004;63:43342.

15. Hulsmans M, Clauss S, Xiao L, Aguirre AD, King KR, Hanley A, et al. Macrophages facilitate electrical conduction in the heart. Cell. 2017;169:510-22 e20.

16.• Adamo L, Rocha-Resende C, Lin C-Y, Evans S, Williams J, Dun $\mathrm{H}$, et al. Myocardial B cells are a subset of circulating lymphocytes with delayed transit through the heart. JCI Insight [Internet]. American Society for Clinical Investigation; 2020 [cited 2020 Mar 2];5. Available from: https://insight.jci.org/articles/view/ 134700. This paper renovates our understanding of B-cell recirculation in the naive state and reveals a novel relationship between B-cells and cardiac diseases.

17. Cordero-Reyes AM, Youker KA, Trevino AR, Celis R, Hamilton DJ, Flores-Arredondo JH, et al. Full expression of cardiomyopathy is partly dependent on B-cells: a pathway that involves cytokine activation, immunoglobulin deposition, and activation of apoptosis. J Am Heart Assoc 2016;5.

18. Zouggari Y, Ait-Oufella H, Bonnin P, Simon T, Sage AP, Guérin $\mathrm{C}$, et al. B lymphocytes trigger monocyte mobilization and impair heart function after acute myocardial infarction. Nat Med. 2013;19:1273-80.

19. Adamo L, Staloch LJ, Rocha-Resende C, Matkovich SJ, Jiang W, Bajpai G, et al. Modulation of subsets of cardiac B lymphocytes improves cardiac function after acute injury. JCI Insight [Internet]. [cited 2020 Mar 2];3. Available from: https://www.ncbi.nlm.nih. gov/pmc/articles/PMC6124442/

20. Wang Y, Gao B, Xiong S. Involvement of NLRP3 inflammasome in CVB3-induced viral myocarditis. Am J Physiol Heart Circ Physiol. 2014;307:H1438-47.

21. Villarreal-Calderón JR, Cuéllar RX, Ramos-González MR, Rubio-Infante N, Castillo EC, Elizondo-Montemayor L, et al. Interplay between the adaptive immune system and insulin resistance in weight loss induced by bariatric surgery. Oxidative Med Cell Longev. 2019;2019:3940739.

22. Camell CD, Günther P, Lee A, Goldberg EL, Spadaro O, Youm $\mathrm{Y}-\mathrm{H}$, et al. Aging induces an Nlrp3 inflammasome-dependent expansion of adipose $\mathrm{b}$ cells that impairs metabolic homeostasis. Cell Metab. 2019;30:1024-39 e6.

23. Vandanmagsar B, Youm Y-H, Ravussin A, Galgani JE, Stadler K, Mynatt RL, et al. The NALP3/NLRP3 inflammasome instigates obesity-induced autoinflammation and insulin resistance. Nat Med. 2011;17:179-88.

24. Castro AM, Macedo-de la Concha LE, Pantoja-Meléndez CA. Low-grade inflammation and its relation to obesity and chronic degenerative diseases. Revista Médica del Hospital General de México. 2017;80:101-5.

25. Sánchez-Trujillo L, Jerjes-Sanchez C, Rodriguez D, Panneflek J, Ortiz-Ledesma C, Garcia-Rivas G, et al. Phase II clinical trial testing the safety of a humanised monoclonal antibody anti-
CD20 in patients with heart failure with reduced ejection fraction, ICFEr-RITU2: study protocol. BMJ Open. 2019;9:e022826.

26. Wang Y, Liu X, Shi H, Yu Y, Yu Y, Li M, et al. NLRP3 inflammasome, an immune-inflammatory target in pathogenesis and treatment of cardiovascular diseases. Clin Transl Med. 2020;10:91-106.

27.• Ridker PM, Everett BM, Thuren T, MacFadyen JG, Chang WH, Ballantyne C, et al. Antiinflammatory therapy with canakinumab for atherosclerotic disease. N Engl J Med. 2017;377:1119-31 Findings from this study suggest that antiinflammatory therapy targeting the interleukin- $1 \beta$ innate immunity led to a significantly lower rate of recurrent cardiovascular events.

28. Van Tassell BW, Trankle CR, Canada JM, Carbone S, Buckley L, Kadariya D, et al. IL-1 blockade in patients with heart failure with preserved ejection fraction. Circ Heart Fail. 2018;11:e005036.

29. Ponikowski P, Voors AA, Anker SD, Bueno H, Cleland JGF, Coats AJS, et al. 2016 ESC guidelines for the diagnosis and treatment of acute and chronic heart failureThe Task Force for the diagnosis and treatment of acute and chronic heart failure of the European Society of Cardiology (ESC) Developed with the special contribution of the Heart Failure Association (HFA) of the ESC. Eur Heart J. 2016;37:2129-200.

30. Cleland JGF, Bunting KV, Flather MD, Altman DG, Holmes J, Coats AJS, et al. Beta-blockers for heart failure with reduced, midrange, and preserved ejection fraction: an individual patient-level analysis of double-blind randomized trials. Eur Heart J. 2018;39: 26-35.

31. Vedin O, Lam CSP, Koh AS, Benson L, Teng THK, Tay WT, et al. Significance of ischemic heart disease in patients with heart failure and preserved, midrange, and reduced ejection fraction: a nationwide cohort study. Circ Heart Fail. 2017;10.

32. Sanders-van Wijk S, van Empel V, Davarzani N, Maeder MT, Handschin R, Pfisterer ME, et al. Circulating biomarkers of distinct pathophysiological pathways in heart failure with preserved vs. reduced left ventricular ejection fraction. Eur J Heart Fail. 2015;17:1006-14.

33. Tromp J, Khan MAF, Mentz RJ, O’Connor CM, Metra M, Dittrich HC, et al. Biomarker profiles of acute heart failure patients with a mid-range ejection fraction. JACC: Heart Failure. 2017;5:507-17.

34. Van Linthout S, Tschöpe C. Inflammation - cause or consequence of heart failure or both? Curr Heart Fail Rep. 2017;14:251-65.

35. Brenes-Castro D, Castillo EC, Vázquez-Garza E, Torre-Amione G, García-Rivas G. Temporal frame of immune cell infiltration during heart failure establishment: lessons from animal models. Int J Mol Sci. 2018;19.

36. Sánchez-Trujillo L, Vázquez-Garza E, Castillo EC, García-Rivas G, Torre-Amione G. Role of adaptive immunity in the development and progression of heart failure: new evidence. Arch Med Res. 2017;48:1-11.

37. Gomberg-Maitland M, Shah SJ, Guazzi M. Inflammation in heart failure with preserved ejection fraction: time to put out the fire. $\mathrm{J}$ Am Coll Cardiol HF. 2016;4:325-8.

38. Vasan RS, Xanthakis V, Lyass A, Andersson C, Tsao C, Cheng S, et al. Epidemiology of left ventricular systolic dysfunction and heart failure in the Framingham study: an echocardiographic study over 3 decades. JACC Cardiovasc Imaging. 2018;11:1-11.

39. Seiler M, Bowen TS, Rolim N, Dieterlen M-T, Werner S, Hoshi T, et al. Skeletal muscle alterations are exacerbated in heart failure with reduced compared with preserved ejection fraction: mediated by circulating cytokines? Circ Heart Fail. 2016;9.

40. Trachtenberg BH, Hare JM. Inflammatory cardiomyopathic syndromes. Circ Res. 2017;121:803-18.

41. Calabrese F, Thiene G. Myocarditis and inflammatory cardiomyopathy: microbiological and molecular biological aspects. Cardiovasc Res Oxford Acad. 2003;60:11-25. 
42. Lindner D, Li J, Savvatis K, Klingel K, Blankenberg S, Tschöpe $\mathrm{C}$, et al. Cardiac fibroblasts aggravate viral myocarditis: cell specific coxsackievirus B3 replication. Mediat Inflamm. 2014;2014: 519528 .

43. Raulet DH. Missing self recognition and self tolerance of natural killer (NK) cells. Semin Immunol. 2006;18:145-50.

44. Groot HE, van Blokland IV, Lipsic E, Karper JC, van der Harst P. Leukocyte profiles across the cardiovascular disease continuum: a population-based cohort study. J Mol Cell Cardiol. 2020;138: $158-64$.

45. Cheng X, Liao Y-H, Ge H, Li B, Zhang J, Yuan J, et al. TH1/TH2 functional imbalance after acute myocardial infarction: coronary arterial inflammation or myocardial inflammation. J Clin Immunol. 2005;25:246-53.

46. Cheng X, Yu X, Ding Y-J, Fu Q-Q, Xie J-J, Tang T-T, et al. The Th17/Treg imbalance in patients with acute coronary syndrome. Clin Immunol. 2008;127:89-97.

47. Puhl S-L, Steffens S. Neutrophils in post-myocardial infarction inflammation: damage vs. resolution? Front Cardiovasc Med. 2019;6:25.

48. Angkananard T, Anothaisintawee T, McEvoy M, Attia J, Thakkinstian A. Neutrophil lymphocyte ratio and cardiovascular disease risk: a systematic review and meta-analysis [Internet]. BioMed Research International. Hindawi; 2018 [cited 2020 May 28]. p. e2703518. Available from: https://www.hindawi. com/journals/bmri/2018/2703518/

49. Jin $\mathrm{P}, \mathrm{Li} \mathrm{X}$, Chen J, Zhang Z, Hu W, Chen L, et al. Platelet-toneutrophil ratio is a prognostic marker for 90 -days outcome in acute ischemic stroke. J Clin Neurosci. 2019;63:110-5.

50. De Luca G, Cavalli G, Campochiaro C, Tresoldi M, Dagna L. Myocarditis: an interleukin-1-mediated disease? Front Immunol. 2018;9:1335

51. Torre-Amione G. Immune activation in chronic heart failure. Am J Cardiol. 2005;95:3C-8C discussion 38C-40C.

52. Horckmans M, Ring L, Duchene J, Santovito D, Schloss MJ, Drechsler M, et al. Neutrophils orchestrate post-myocardial infarction healing by polarizing macrophages towards a reparative phenotype. Eur Heart J Oxford Academic. 2017;38:187-97.

53. Woldbaek PR, Sande JB, Strømme TA, Lunde PK, Djurovic S, Lyberg T, et al. Daily administration of interleukin-18 causes myocardial dysfunction in healthy mice. Am J Physiol Heart Circ Physiol. 2005;289:H708-14.

54. Toldo S, Kannan H, Bussani R, Anzini M, Sonnino C, Sinagra G, et al. Formation of the inflammasome in acute myocarditis. Int J Cardiol; Elsevier. 2014;171:e119-21.

55. Szekely Y, Arbel Y. A review of interleukin-1 in heart disease: where do we stand today? Cardiol Ther. 2018;7:25-44.

56. Zell R, Geck P, Werdan K, Boekstegers P. TNF-alpha and IL-1 alpha inhibit both pyruvate dehydrogenase activity and mitochondrial function in cardiomyocytes: evidence for primary impairment of mitochondrial function. Mol Cell Biochem. 1997;177: 61-7.

57. Liu SJ, Zhou W, Kennedy RH. Suppression of $\beta$-adrenergic responsiveness of L-type Ca2+ current by IL- $1 \beta$ in rat ventricular myocytes. Am J Physiol-Heart Circulat Physiol Am Physiol Soc. 1999;276:H141-8.

58. Baum JR, Long B, Cabo C, Duffy HS. Myofibroblasts cause heterogeneous $\mathrm{Cx} 43$ reduction and are unlikely to be coupled to myocytes in the healing canine infarct. Am J Physiol-Heart Cir Physiol Am Physiol Soc. 2011;302:H790-800.

59. Leung BP, Culshaw S, Gracie JA, Hunter D, Canetti CA, Campbell $\mathrm{C}$, et al. A role for IL-18 in neutrophil activation. J Immunol Am Assoc Immunol. 2001;167:2879-86.

60. Yamaoka-Tojo M, Tojo T, Inomata T, Machida Y, Osada K, Izumi T. Circulating levels of interleukin 18 reflect etiologies of heart failure: Th1/Th2 cytokine imbalance exaggerates the pathophysiology of advanced heart failure. J Card Fail. 2002;8:21-7.

61. Di Somma S, Pittoni V, Raffa S, Magrini L, Gagliano G, Marino R, et al. IL-18 stimulates B-type natriuretic peptide synthesis by cardiomyocytes in vitro and its plasma levels correlate with B-type natriuretic peptide in non-overloaded acute heart failure patients. Eur Heart J Acute Cardiovasc Care. 2017;6:450-61.

62. Buckley LF, Abbate A. Interleukin-1 blockade in cardiovascular diseases: a clinical update. Eur Heart J Oxford Academic. 2018:39:2063-9.

63. Marchetti C, Chojnacki J, Toldo S, Mezzaroma E, Tranchida N, Rose SW, et al. A novel pharmacologic inhibitor of the NLRP3 inflammasome limits myocardial injury after ischemia-reperfusion in the mouse. J Cardiovasc Pharmacol. 2014;63:316-22.

64. Lipinski MJ, Frias JC. Molecule 16673-34-0: a new tool in our arsenal against inflammation. J Cardiovasc Pharmacol. 2014;63: 314-5.

65. Yoshimoto T, Takeda K, Tanaka T, Ohkusu K, Kashiwamura S, Okamura H, et al. IL-12 up-regulates IL-18 receptor expression on T cells, Th1 cells, and B cells: synergism with IL-18 for IFNgamma production. J Immunol. 1998;161:3400-7.

66. Opstad TB, Arnesen H, Pettersen A $\AA$, Seljeflot I. Combined elevated levels of the proinflammatory cytokines IL-18 and IL-12 are associated with clinical events in patients with coronary artery disease: an observational study. Metab Syndr Relat Disord. 2016;14:242-8.

67. Deenick EK, Hasbold J, Hodgkin PD. Decision criteria for resolving isotype switching conflicts by B cells. Eur J Immunol. 2005;35:2949-55.

68. Ali MF, Dasari H, Van Keulen VP, Carmona EM. Canonical stimulation of the NLRP3 inflammasome by fungal antigens links innate and adaptive B-lymphocyte responses by modulating IL$1 \beta$ and IgM production. Front Immunol [Internet]. 2017 [cited 2020 Mar 2];8. Available from: https://www.ncbi.nlm.nih.gov/ pmc/articles/PMC5684107/

69. Kallikourdis M, Martini E, Carullo P, Sardi C, Roselli G, Greco $\mathrm{CM}$, et al. T cell costimulation blockade blunts pressure overloadinduced heart failure. Nat Commun. 2017;8:14680.

70. Egeberg A, Skov L, Joshi AA, Mallbris L, Gislason GH, Wu JJ, et al. The relationship between duration of psoriasis, vascular inflammation, and cardiovascular events. J Am Acad Dermatol. 2017;77:650-6 e3.

71. Fajemiroye JO, da Cunha LC, Saavedra-Rodríguez R, Rodrigues KL, Naves LM, Mourão AA, et al. Aging-induced biological changes and cardiovascular diseases [Internet]. BioMed Research International. Hindawi; 2018 [cited 2020 May 26]. p. e7156435. Available from: https://www.hindawi.com/journals/ bmri/2018/7156435/

72.• Schiattarella GG, Altamirano F, Tong D, French KM, Villalobos E, Kim SY, et al. Nitrosative stress drives heart failure with preserved ejection fraction. Nature. 2019;568:351-6 This study report that metabolic and hypertensive stress in mice recapitulates the several systemic and cardiovascular features of HFpEF in humans, suggesting a feasiable model of translation for HFpEF.

73. Nazha H, Constantijn F, André L, Inês F-P, Dulce F, Sara L, et al. Myocardial Titin hypophosphorylation importantly contributes to heart failure with preserved ejection fraction in a rat metabolic risk model. Circulation: Heart Failure American Heart Association. 2013;6:1239-49.

74. Curl CL, Danes VR, Bell JR, Raaijmakers AJA, Ip WTK, Chandramouli $\mathrm{C}$, et al. Cardiomyocyte functional etiology in heart failure with preserved ejection fraction is distinctive - a new preclinical model. J Am Heart Assoc: Cardiovascular and Cerebrovascular Disease [Internet]. Wiley-Blackwell; 2018 [cited 
2020 May 27];7. Available from: https://www.ncbi.nlm.nih.gov/ pmc/articles/PMC6015350/

75. Sorop O, Heinonen I, van Kranenburg M, van de Wouw J, de Beer VJ, Nguyen ITN, et al. Multiple common comorbidities produce left ventricular diastolic dysfunction associated with coronary microvascular dysfunction, oxidative stress, and myocardial stiffening. Cardiovasc Res. 2018;114:954-64.

76. Tao L, Reese TA. Making mouse models that reflect human immune responses. Trends Immunol. 2017;38:181-93.

77. Franssen C, Chen S, Unger A, Korkmaz HI, De Keulenaer GW, Tschöpe C, et al. Myocardial microvascular inflammatory endothelial activation in heart failure with preserved ejection fraction. JACC: Heart Failure. 2016;4:312-24.

78. McDonnell ME, Ganley-Leal LM, Mehta A, Bigornia SJ, Mott M, Rehman Q, et al. B lymphocytes in human subcutaneous adipose crown-like structures. Obesity (Silver Spring). 2012;20:1372-8.

79. Frasca D, Diaz A, Romero M, Thaller S, Blomberg BB. Secretion of autoimmune antibodies in the human subcutaneous adipose tissue. PLoS One. 2018;13:e0197472.

80. Benraoune F, Litwin SE. Reductions in cardiovascular risk after bariatric surgery. Curr Opin Cardiol. 2011;26:555-61.

81. Castillo EC, Morales JA, Chapoy-Villanueva H, Silva-Platas C, Treviño-Saldaña N, Guerrero-Beltrán CE, et al. Mitochondrial hyperacetylation in the failing hearts of obese patients mediated partly by a reduction in SIRT3: the involvement of the mitochondrial permeability transition pore. Cell Physiol Biochem. 2019;53: 465-79.

82. Riojas-Hernández A, Bernal-Ramírez J, Rodríguez-Mier D, Morales-Marroquín FE, Domínguez-Barragán EM, Borja-Villa $\mathrm{C}$, et al. Enhanced oxidative stress sensitizes the mitochondrial permeability transition pore to opening in heart from Zucker Fa/ fa rats with type 2 diabetes. Life Sci. 2015;141:32-43.

83. Sverdlov AL, Aly E, Fuzhong Q, Behring Jessica B, Ivan L, Calamaras Timothy D, et al. Mitochondrial reactive oxygen species mediate cardiac structural, functional, and mitochondrial consequences of diet-induced metabolic heart disease. J Am Heart Assoc Am Heart Assoc. 5:e002555.

84. Pérez-Treviño P, Velásquez M, García N. Mechanisms of mitochondrial DNA escape and its relationship with different metabolic diseases. Biochim Biophys Acta (BBA) - Mol Basis Dis. 2020;1866:165761

85. Yao X, Carlson D, Sun Y, Ma L, Wolf SE, Minei JP, et al. Mitochondrial ROS induces cardiac inflammation via a pathway through mtDNA damage in a pneumonia-related sepsis model. PLoS One. Public Libr Sci. 2015;10:e0139416.

86. Platis A, Yu Q, Moore D, Khojeini E, Tsau P, Larson D. The effect of daily administration of IL-18 on cardiac structure and function. Perfusion. 2008;23:237-42.

87. Sokolova M, Sjaastad I, Louwe MC, Alfsnes K, Aronsen JM, Zhang L, et al. NLRP3 inflammasome promotes myocardial remodeling during diet-induced obesity. Front Immunol [Internet]. Frontiers; 2019 [cited 2020 May 28];10. Available from: https:// www.frontiersin.org/articles/10.3389/fimmu.2019.01621/full

88. Cohen RA, Tong X. Vascular oxidative stress: the common link in hypertensive and diabetic vascular disease. J Cardiovasc Pharmacol. 2010;55:308-16.

89. Zhou R, Yazdi AS, Menu P, Tschopp J. A role for mitochondria in NLRP3 inflammasome activation. Nature. 2011;469:221-5.

90. Chaudhary KR, El-Sikhry H, Seubert JM. Mitochondria and the aging heart. J Geriatr Cardiol. 2011;8:159-67.

91. Rajapakse AG, Yepuri G, Carvas JM, Stein S, Matter CM, Scerri I, et al. Hyperactive S6K1 mediates oxidative stress and endothelial dysfunction in aging: inhibition by resveratrol. PLoS One [Internet]. 2011 [cited 2020 May 27];6. Available from: https:// www.ncbi.nlm.nih.gov/pmc/articles/PMC3081344/
92. Calderone A, Thaik CM, Takahashi N, Chang DL, Colucci WS. Nitric oxide, atrial natriuretic peptide, and cyclic GMP inhibit the growth-promoting effects of norepinephrine in cardiac myocytes and fibroblasts. J Clin Invest American Society for Clinical Investigation. 1998;101:812-8.

93. Kim CH, Tofovic D, Chami T, Al-Kindi SG, Oliveira GH. Subtypes of heart failure in autoimmune diseases. J Card Fail. Elsevier. 2017;23:S22.

94. Breunig M, Morbach C, Kleinert S, Tony HP, Angermann CE, Stoerk S. P5422 Cardiovascular risk and death in patients with rheumatic diseases and heart failure with preserved ejection fraction. Eur Heart J [Internet]. Oxford Academic; 2018 [cited 2020 May 28];39. Available from: https://academic.oup.com/eurheartj/ article/39/suppl_1/ehy566.P5422/5084101

95. Nicola PJ, Maradit-Kremers H, Roger VL, Jacobsen SJ, Crowson $\mathrm{CS}$, Ballman KV, et al. The risk of congestive heart failure in rheumatoid arthritis: a population-based study over 46 years. Arthritis Rheum. 2005;52:412-20.

96. Wu Q, Zhou L, Sun X, Yan Z, Hu C, Wu J, et al. Altered lipid metabolism in recovered SARS patients twelve years after infection. Sci Rep Nat Publ Group. 2017;7:1-12.

97. Ye Q, Wang B, Mao J. The pathogenesis and treatment of the 'cytokine storm' in COVID-19. J Inf Secur. 2020.

98. Zhou W, Chen C, Chen Z, Liu L, Jiang J, Wu Z, et al. NLRP3: a novel mediator in cardiovascular disease [Internet]. Journal of Immunology Research. Hindawi; 2018 [cited 2020 May 29]. p. e5702103. Available from: https://www.hindawi.com/journals/jir/ 2018/5702103/

99. Van Tassell BW, Canada J, Carbone S, Trankle C, Buckley L, Oddi Erdle C, et al. Interleukin-1 blockade in recently decompensated systolic heart failure: results from REDHART (recently decompensated heart failure Anakinra response trial). Circ Heart Fail $2017 ; 10$.

100. Anakinra to prevent adverse post-infarction remodeling (2) - full text view - ClinicalTrials.gov [Internet]. [cited 2020 Jun 12]. Available from: https://clinicaltrials.gov/ct2/show/NCT01175018

101. Novartis Pharmaceuticals. A randomized, double-blind, placebocontrolled, event-driven trial of quarterly subcutaneous canakinumab in the prevention of recurrent cardiovascular events among stable post-myocardial infarction patients with elevated hsCRP [Internet]. clinicaltrials.gov; 2020 Jan. Report No.: NCT01327846. Available from: https://clinicaltrials.gov/ct2/ show/NCT01327846

102. Van Tassell BW, Abouzaki NA, Oddi Erdle C, Carbone S, Trankle CR, Melchior RD, et al. Interleukin-1 blockade in acute decompensated heart failure: a randomized, double-blinded, placebo-controlled pilot study. J Cardiovasc Pharmacol. 2016;67:544-51.

103. Trankle CR, Canada JM, Cei L, Abouzaki N, Oddi-Erdle C, Kadariya D, et al. Usefulness of canakinumab to improve exercise capacity in patients with Long-term systolic heart failure and elevated C-reactive protein. Am J Cardiol. 2018;122:1366-70.

104. Selzman C Interleukin-1 receptor antagonist for the treatment of heart failure in patients with left ventricular assist devices [Internet]. clinicaltrials.gov; $2020 \mathrm{Feb}$. Report No.: NCT02547766. Available from: https://clinicaltrials.gov/ct2/ show/NCT02547766

105. Pilot Feasibility Study of the Safety and Efficacy of Anakinra in Heart Failure With Preserved Ejection Fraction - Full Text View ClinicalTrials.gov [Internet]. [cited 2020 Jun 11]. Available from: https://clinicaltrials.gov/ct2/show/NCT01542502

106. Van Tassell BW, Lipinski MJ, Appleton D, Roberts CS, Kontos MC, Abouzaki N, et al. Rationale and design of the Virginia Commonwealth University-Anakinra Remodeling Trial-3 (VCUART3): a randomized, placebo-controlled, double-blinded, multicenter study. Clin Cardiol. 2018;41:1004-8. 
107. Cavalli G, Pappalardo F, Mangieri A, Dinarello CA, Dagna L, Tresoldi M. Treating life-threatening myocarditis by blocking interleukin-1. Crit Care Med. 2016;44:e751-4.

108. Cavalli G, Foppoli M, Cabrini L, Dinarello CA, Tresoldi M, Dagna L. Interleukin-1 receptor blockade rescues myocarditisassociated end-stage heart failure. Front Immunol [Internet]. Frontiers; 2017 [cited 2020 May 28];8. Available from: https:// www.frontiersin.org/articles/10.3389/fimmu.2017.00131/full

109. Ignatios I, Lekakis JP, Maria N, Ioannis P, Ioanna A, Theophania $\mathrm{K}$, et al. Inhibition of interleukin-1 by Anakinra improves vascular and left ventricular function in patients with rheumatoid arthritis. Circulation Am Heart Assoc. 2008;117:2662-9.

110. Ikonomidis I, Tzortzis S, Andreadou I, Paraskevaidis I, Katseli C, Katsimbri P, et al. Increased benefit of interleukin-1 inhibition on vascular function, myocardial deformation, and twisting in patients with coronary artery disease and coexisting rheumatoid arthritis. Circ Cardiovasc Imaging. 2014;7:619-28.

111. Ridker PM, MacFadyen JG, Thuren T, Libby P. Residual inflammatory risk associated with interleukin-18 and interleukin-6 after successful interleukin-1 $\beta$ inhibition with canakinumab: further rationale for the development of targeted anti-cytokine therapies for the treatment of atherothrombosis. Eur Heart J 2019;

112. Febbraio MA. Role of interleukins in obesity: implications for metabolic disease. Trends Endocrinol Metab. 2014;25:312-9.

113. van den Hoogen P, de Jager SCA, Huibers MMH, Schoneveld $\mathrm{AH}$, Puspitasari YM, Valstar GB, et al. Increased circulating IgG levels, myocardial immune cells and $\mathrm{IgG}$ deposits support a role for an immune response in pre- and end-stage heart failure. J Cell Mol Med. 2019;23:7505-16.

114. Jackson CE, Haig C, Welsh P, Dalzell JR, Tsorlalis IK, McConnachie A, et al. Combined free light chains are novel predictors of prognosis in heart failure. JACC: Heart Failure. 2015;3: 618-25.

115. Anandram S, Assi LK, Lovatt T, Parkes J, Taylor J, Macwhannell A, et al. Elevated, combined serum free light chain levels and increased mortality: a 5-year follow-up. UK study J Clin Pathol. 2012;65:1036-42.

116. Torre-Amione G, Orrego CM, Khalil N, Kottner-Assad C, Leveque C, Celis R, et al. Therapeutic plasma exchange a potential strategy for patients with advanced heart failure. J Clin Apher. 2010;25:323-30.

117. Chan CT, Sobey CG, Lieu M, Ferens D, Kett MM, Diep H, et al. Obligatory role for B cells in the development of angiotensin IIdependent hypertension. Hypertension. 2015;66:1023-33.

118. Tschöpe C, Van Linthout S, Spillmann F, Posch MG, Reinke P, Volk H-D, et al. Targeting CD20+ B-lymphocytes in inflammatory dilated cardiomyopathy with rituximab improves clinical course: a case series. Eur Heart J Case Rep. 2019;3.

119. Rituximab in patients with acute ST-elevation myocardial infarction study - full text view - ClinicalTrials.gov [Internet]. [cited 2019 Oct 24]. Available from: https://clinicaltrials.gov/ct2/show/ NCT03072199

120. García-Rivas G, Castillo EC, Gonzalez-Gil AM, MaravillasMontero JL, Brunck M, Torres-Quintanilla A, et al. The role of $\mathrm{B}$ cells in heart failure and implications for future immunomodulatory treatment strategies. ESC Heart Fail. 2020;

121. Flores-Arredondo JH, García-Rivas G, Torre-Amione G. Immune modulation in heart failure: past challenges and future hopes. Curr Heart Fail Rep. 2011;8:28-37.

122. Chung ES, Packer M, Lo KH, Fasanmade AA, Willerson JT, Anti-TNF therapy against congestive heart failure investigators. Randomized, double-blind, placebo-controlled, pilot trial of infliximab, a chimeric monoclonal antibody to tumor necrosis factor-alpha, in patients with moderate-to-severe heart failure: results of the anti-TNF Therapy Against Congestive Heart Failure (ATTACH) trial. Circulation. 2003;107:3133-40.
123. Mann DL, McMurray JJV, Packer M, Swedberg K, Borer JS, Colucci WS, et al. Targeted anticytokine therapy in patients with chronic heart failure: results of the Randomized Etanercept Worldwide Evaluation (RENEWAL). Circulation. 2004;109: 1594-602.

124. Jerjes-Sánchez C. García-Rivas G, Rodriguez D, Torre-Amione G. Phase I, Single Center, Open-label study of cannabidiol in patients with heart failure in AHA/ACC stages A-C [Internet]. clinicaltrials.gov; 2019 Aug. Report No.: NCT03634189. Available from: https://clinicaltrials.gov/ct2/show/NCT03634189

125. Resveratrol: a potential anti- remodeling agent in heart failure, from bench to bedside - full text view - ClinicalTrials.gov [Internet]. [cited 2020 Jun 12]. Available from: https:// clinicaltrials.gov/ct2/show/NCT01914081

126. Ananthasubramaniam $\mathrm{K}$ Effects of pentoxiphylline on left ventricular systolic function indices and circulating biomarkers in patients with chronic congestive heart failure. [Internet]. clinicaltrials.gov; 2013 Aug. Report No.: NCT01337349. Available from: https://clinicaltrials.gov/ct2/show/NCT01337349

127. MD DE. HEMolysis in a percutaneous axial flow left ventricular assist device, effects of pentoxifylline in a randomized controlled trial [Internet]. clinicaltrials.gov; 2020 May. Report No.: NCT04391231. Available from: https://clinicaltrials.gov/ct2/ show/NCT04391231

128. Tardif J-C, Kouz S, Waters DD, Bertrand OF, Diaz R, Maggioni AP, et al. Efficacy and safety of low-dose colchicine after myocardial infarction. New England Journal of Medicine Massachusetts Medical Society. 2019;381:2497-505.

129. Deftereos S, Giannopoulos G, Panagopoulou V, Bouras G, Raisakis K, Kossyvakis C, et al. Anti-inflammatory treatment with colchicine in stable chronic heart failure: a prospective. Randomized Study JACC: Heart Failure. 2014;2:131-7.

130. Moreira DM. METhotrexate therapy effects in the physical capacity of patients with ischemic heart failure: randomized doubleblind, placebo-controlled trial (METIS Trial) [Internet]. clinicaltrials.gov; 2013 Mar. Report No.: NCT00759811. Available from: https://clinicaltrials.gov/ct2/show/NCT00759811

131. Pelliccia F Effects of thalidomide on left ventricular morphology and function in patients with congestive heart failure - the THUNDER Trial [Internet]. clinicaltrials.gov; 2013 Mar. Report No.: NCT01640639. Available from: https://clinicaltrials.gov/ct2/ show/NCT01640639

132. Bartolucci J. Phase 1 randomized-double blind clinical trial of intravenous infusion of umbilical cord mesenchymal stem cells transplantation in heart failure on patients with cardiopathy in dilated stage, of different etiology [Internet]. clinicaltrials.gov; 2015 Jun. Report No.: NCT01739777. Available from: https:// clinicaltrials.gov/ct2/show/NCT01739777

133. Nodari S Effects of n-3 polyunsaturated fatty acids (PUFAs) on left ventricular function and functional capacity in patients with dilated cardiomyopathy [Internet]. clinicaltrials.gov; 2012 Jan. Report No.: NCT01223703. Available from: https://clinicaltrials. gov/ct2/show/NCT01223703

134. McNamara DM, Holubkov R, Starling RC, Dec GW, Loh E, Torre-Amione $\mathrm{G}$, et al. Controlled trial of intravenous immune globulin in recent-onset dilated cardiomyopathy. Circulation. 2001;103:2254-9.

135. Torre-Amione G, Sestier F, Radovancevic B, Young J. Broad modulation of tissue responses (immune activation) by celacade may favorably influence pathologic processes associated with heart failure progression. Am J Cardiol. 2005;95:30C-7C discussion 38C-40C.

136. Hummel SL. GRAPe seed extract and ventriculovascular investigation in normal ejection-fraction heart failure [Internet]. clinicaltrials.gov; 2017 Jun. Report No.: NCT01185067. Available from: https://clinicaltrials.gov/ct2/show/NCT01185067 
137. University of Alberta. Evaluating the clinical efficacy of resveratrol in improving metabolic and skeletal muscle function in patients with heart failure [Internet]. clinicaltrials.gov; 2020 Mar. Report No.: NCT03525379. Available from: https://clinicaltrials. gov/ct2/show/NCT03525379

138. Oropeza-Almazán Y, Vázquez-Garza E, Chapoy-Villanueva H, Torre-Amione G, García-Rivas G. Small interfering RNA targeting mitochondrial calcium uniporter improves cardiomyocyte cell viability in hypoxia/reoxygenation injury by reducing calcium overload. Oxidative Med Cell Longev. 2017;2017: 5750897.

139. Lozano O, García-Rivas G, Ramos M, Vázquez-Garza E, Chapoy-Villanueva H, Rubio N, et al. Cardioprotective effect of cannabidiol in a non ischemic model of heart failure. J Am Coll Cardiol. 2020;75:705.

140. Schüller SS, Wisgrill L, Herndl E, Spittler A, Förster-Waldl E, Sadeghi K, et al. Pentoxifylline modulates LPS-induced hyperinflammation in monocytes of preterm infants in vitro. Pediatr Res. 2017;82:215-25.

141. Sliwa K, Skudicky D, Candy G, Wisenbaugh T, Sareli P. Randomised investigation of effects of pentoxifylline on leftventricular performance in idiopathic dilated cardiomyopathy. Lancet. 1998:351:1091-3.

142. Karen S, Angela W, Kone VN, Geoffrey C, Danelle B, Gavin N, et al. Therapy of ischemic cardiomyopathy with the immunomodulating agent pentoxifylline. Cir Am Heart Assoc. 2004;109:750-5.
143. Jain MK, Ridker PM. Anti-inflammatory effects of statins: clinical evidence and basic mechanisms. Nature Reviews Drug Discovery Nature Publishing Group. 2005;4:977-87.

144. Tavazzi L, Maggioni AP, Marchioli R, Barlera S, Franzosi MG, Latini R, et al. Effect of rosuvastatin in patients with chronic heart failure (the GISSI-HF trial): a randomised, double-blind, placebocontrolled trial. Lancet. 2008;372:1231-9.

145. Jahng JWS, Song E, Sweeney G. Crosstalk between the heart and peripheral organs in heart failure. Exp Mol Med. 2016;48:e217.

146. Lozano O, Lázaro-Alfaro A, Silva-Platas C, Oropeza-Almazán Y, Torres-Quintanilla A, Bernal-Ramírez J, et al. Nanoencapsulated quercetin improves cardioprotection during hypoxiareoxygenation injury through preservation of mitochondrial function. Oxidative Med Cell Longev. 2019;2019:7683051.

147. Sano S, Oshima K, Wang Y, MacLauchlan S, Katanasaka Y, Sano $\mathrm{M}$, et al. Tet2-mediated clonal hematopoiesis accelerates heart failure through a mechanism involving the IL-1ß/NLRP3 inflammasome. J Am Coll Cardiol. 2018;71:875-86.

148. Brezinschek H-P, Rainer F, Brickmann K, Graninger WB. B lymphocyte-typing for prediction of clinical response to rituximab. Arthritis Res Ther. 2012;14:R161.

Publisher's Note Springer Nature remains neutral with regard to jurisdictional claims in published maps and institutional affiliations. 